\title{
Arkadiusz Bereza, Lublin jako ośrodek sądownictwa, Lublin 2006, 140 stron.
}

W literaturze historycznoprawnej nie ma wyczerpującej monografii poświęconej dziejom polskiego wymiaru sprawiedliwości. Dlatego też każda publikacja na ten temat stanowi kolejny krok do odkrywania kart jego historii. Wydana w 2006 r. praca Arkadiusza Berezy stanowi interesującą pozycję, przybliżającą historię sądownictwa lubelskiego od wczesnego średniowiecza do czasów współczesnych. Ze wstępu wynika, że autor, pisząc swoją książkę, chciał zrealizować dwa podstawowe cele: pierwszy - to pielęgnacja tradycji wymiaru sprawiedliwości, drugi - to realizacja postulatu gromadzenia wiedzy o postaciach z kręgu praktyki prawa z myślą o ocaleniu ich przed zapomnieniem. Moim zdaniem, autor w pełni cele te zrealizował.

We wstępie pracy autor zwrócił uwagę na pewien paradoks, polegający na tym, iż najwięcej problemów badawczych związanych z dotarciem do źródeł historycznych miał przy odtwarzaniu dziejów sądownictwa lubelskiego, począwszy od pierwszej połowy XIX w. Poradził sobie z nimi przez wykorzystanie pamiętników, dzienników urzędowych, przekazów ustnych oraz zwiedzanie kamienic, pałaców, tj. historycznych siedzib sądów.

Cenną zaletą recenzowanej książki jest zawarty w niej opis dziejów sądownictwa w Lublinie na tle przemian wymiaru sprawiedliwości w ogóle w Polsce. Jest on bardzo klarowny i interesujący. I tak, dowiadujemy się, że początki sądownictwa na Lubelszczyźnie sięgają wczesnego średniowiecza, kiedy to rozwijający się w ośrodek miejski gród kasztelański Lublin (prawa miejskie nadane w 1317 r.) stawał się centrum życia politycznego i sądowego. Organizacja i struktura sądownictwa na przestrzeni wieków ulegała zmianom, które były determinowane przez rozwój gospodarczy, polityczny i administracyjny tego obszaru, ale też burzliwą historią Polski, na którą składały się w szczególności okresy zaborów oraz I i II wojny światowej. Polskie lubelskie sądy powszechne rozpoczęły swą działalność w dniu 1 września 1917 r. W Lublinie miały swą siedzibę: Sąd Apelacyjny, Sąd Okręgowy oraz trzy (później cztery) sądy pokoju. Wszystkie orzekały kolegialnie w składach zawodowych bądź z udziałem ławników. Jurysdykcji lubelskiego Sądu Apelacyjnego podlegały, oprócz Sądu Okręgowego w Lublinie, także Sądy Okręgowe w Kielcach, Radomiu i Piotrkowie. Zasięg apelacji lubelskiej i właściwość miejscowa Sądu Okręgowego w Lublinie ulegały ciągłym zmianom.

W okresie międzywojennym organizacja sądów, wykształcona w latach 1915-1919, utrzymana została w podstawowych założeniach i obowiązywała do unifikacji ustroju sądownictwa powszechnego, tj. do dnia 31 grudnia $1928 \mathrm{r}$.

Wybuch II wojny światowej w istotny sposób zakłócił funkcjonowanie lubelskich sądów, które po klęsce wrześniowej wznowiły działalność dopiero w pierwszym kwartale 1940 r. i orzekały równolegle z powszechnymi niemieckimi sądami I i II instancji, doraźnymi sądami policyjnymi i sądem specjalnym. 
Godne uwagi są rozważania autora na temat losów sędziów zaraz po ustanowieniu w lipcu 1944 r. siedziby komunistycznych, tymczasowych władz w Lublinie. Straty sądowników lubelskich sięgały około 50\% stanu przedwojennego. Kadrę tę poszerzono o sędziów i prokuratorów z Kielc i Radomia, którzy uwięzieni przez oddziały Armii Czerwonej zostali uwolnieni dzięki interwencji lubelskich władz tymczasowych. Zezwalano im tylko na pracę w adwokaturze. Przedwojenni sędziowie lubelscy odmawiali propozycjom zatrudnienia w resorcie sprawiedliwości PKWN. Ten wątek - moim zdaniem - zasługuje na pogłębienie, głównie ze względu na fakt, iż właśnie m.in. w Lublinie miały miejsce pierwsze wydarzenia związane z początkami wymiaru sprawiedliwości Polski Ludowej.

Autor w swojej pracy drobiazgowo opisuje strukturę wewnętrzną sądów, ich skład osobowy, ubiór sędziów, wymienia ulice przy których stały bądź stoją budynki sądowe. I być może z jednej strony momentami ta ilość szczegółów przytłacza, ale z drugiej - uwiarygodnia i uświadamia „fizyczną” wręcz obecność przeszłości w teraźniejszości.

Na koniec chciałbym podkreślić - co jest ogromnym walorem książki - jej kunszt edytorski. W twardej obwolucie, na kredowym papierze, 78 fotografii upamiętniających dokumenty, rekwizyty, budynki i postaci związane $\mathrm{z}$ funkcjonowaniem sądów w Lublinie. Ta dbałość o estetykę wydania powoduje, że zaglądam do niej z przyjemnością po raz kolejny. 